\section{ZEW}

Zentrum für Europäische Wirtschaftsforschung GmbH

Centre for European Economic Research

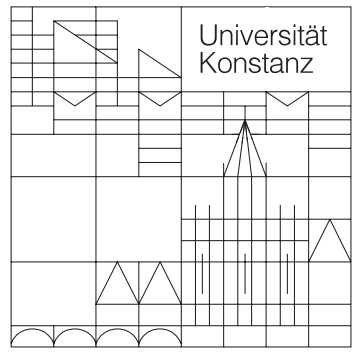

Rechts-, Wirtschafts- und Verwaltungswissenschaftliche Sektion Fachbereich

Wirtschaftswissenschaften

Diskussionspapiere der DFG-

Forschergruppe (Nr.: 3468269275):

Heterogene Arbeit: Positive und Normative Aspekte der Qualifikationsstruktur der Arbeit

Erik E. Lehmann

Does Venture Capital Syndication Spur Employment Growth and Shareholder Value? Evidence from German IPO Data

Mai 2004 
Diskussionspapier der Forschergruppe (Nr.: 3468269275) "Heterogene Arbeit: Positive und Normative Aspekte der Qualifikationsstruktur der Arbeit"

Nr. 04/11, Mai 2004

\title{
Does Venture Capital Syndication Spur Employment Growth and Shareholder Value? Evidence from German IPO Data
}

\section{Erik E. Lehmann}

\author{
Universität Konstanz \\ Fachbereich Wirtschaftswissenschaften \\ Fach D144 \\ 78457 Konstanz \\ Germany \\ mail: erik.lehmann@uni-konstanz.de \\ phone: +49-7531-88-2968 \\ fax +49-7531-88-4456
}

\section{Zusammenfassung:}

This study examines empirically the syndication of equity by multiple venture capitalists in Germany. Following the literature, there are mainly two competing views as to why venture capitalists syndicate investments. First, syndication can be viewed as a means of risk-sharing. Second, venture capitalists may provide important productive resources to firms, capital and information. We test hypotheses based on these two aspects. The results show that the syndication of equity and the number of venture capitalists involved cannot be fully explained by firm characteristics like size, age or industry affiliation. Although syndicated investments do not differ significantly in stock-market performance, they show significantly higher growth rates. 


\title{
Does Venture Capital Syndication Spur Employment Growth and Shareholder Value?
}

\section{Evidence from German IPO Data}

\author{
Erik E. Lehmann* \\ University of Konstanz
}

02/04/04 3:49

\begin{abstract}
This study examines empirically the syndication of equity by multiple venture capitalists in Germany. Following the literature, there are mainly two competing views as to why venture capitalists syndicate investments. First, syndication can be viewed as a means of risk-sharing. Second, venture capitalists may provide important productive resources to firms, capital and information. We test hypotheses based on these two aspects. The results show that the syndication of equity and the number of venture capitalists involved cannot be fully explained by firm characteristics like size, age or industry affiliation. Although syndicated investments do not differ significantly in stock-market performance, they show significantly higher growth rates.
\end{abstract}

Key Words: Venture Capital, Human Capital; Syndication, Firm Performance

\footnotetext{
* Department of Economics, University of Konstanz, Box 144, D 78457 Konstanz. E-mail: erik.lehmann@uni-konstanz.de. Phone: ++49 (0) 753188 2968. I am grateful to David B. Audretsch, Cathy Bonsor-Neale, Greg Udell, Susanne Warning, and Adam Lederer. However, the usual disclaimer applies. Financial support by the German Research Foundation (DFG) through the research group \#FOR454 "Heterogenous Labor" at the University of Konstanz and the ZEW, Mannheim, is gratefully acknowledged.
} 


\section{Executive Summary}

Despite the crucial role venture capitalists play in financing high-tech firms, there is disproportionally little attention in the academic literature on venture capital syndication. Although some firms are backed by a sole venture capitalist, a closer look at the working practice of the venture capitalist industry shows striking evidence that investments are often undertaken by more than one venture capitalist. This practice of financing firms by two or more venture capitalists, called syndication, involves different venture capital firms taking an equity stake in the firm. In the presence of team-effects and the resulting moral-hazard incentives, the still remaining question is, why venture capitalists syndicate private equity, when the practice of syndication may create both, ex-ante and ex-post managerial problems.

Following the literature, there are mainly two competing views as to why venture capitalists syndicate investments. First, syndication can be viewed as a means of risksharing. Second, venture capitalists may provide important productive resources to firms, capital and information. While the first perspective looks only at the risk-diversification side of the venture capitalist, the second perspective focuses more on the strategic aspects of syndication in providing necessary tangible (equity) and intangible (information) assets.

These questions are addressed empirically in this paper using a hand collected dataset of German IPOs. Unlike to the US or UK, Germany suffers from having a less developed capital market and a less vibrant venture capital industry. Although being the third-largest economy in the World (behind the US and Japan), Germany is associated with 
considerably lower growth rates of per capita and of total factor productivity. The vibrant venture capital industry is seen as one of the cornerstones of America's leadership in the commercialization of technological innovation. Thus, the lack of a developed venture capital industry to finance young and high-risky firms is one explanation for lower growth rates in Germany in the past ten years. Although it is proclaimed to be the largest venture capital market in continental Europe, there is only scarce empirical evidence about the determinants and the success of venture-backed firms in Germany.

This study links venture capital syndication to performance measures like firm growth and stock market performance for German IPOs. The results show that both the likelihood of syndication and the number of venture capitalists cannot be fully explained by firm characteristics like age, size, and industry effects. However, the study provides evidence of the risk-sharing argument. The equity shares held by venture capitalists are higher in syndicated investments and the average size of equity held by venture capitalists is significantly lower compared to standalone investments.

The study also supports the hypothesis that syndicated ventures show higher growth rates than standalone ventures. This may provide further evidence for the value-adding hypothesis of venture capital syndication. The results also show that the resources provided by multiple venture capitalists lead to higher growth rates by overcoming growth restrictions, but may not necessarily lead to higher returns on the stock market. However, the stock market evaluates the trade-off between the costs and benefits of syndicated firms as the same as for standalone investments. 
Thus, from the standpoint of policy makers who are interested in higher growth rates of employees, as it should be the case for Germany, the syndication of equity by venture capitalists should be fostered.

\section{Introduction}

Venture capitalists play a crucial role in the economy for at least two reasons. First, they incubate new and small firms by supplying them with equity capital (Gohrman/Sahlman, 1989). Second, they bring firms to public and thus increase their equity base to finance their future growth (Cumming/MacIntosh, 2003; Kaplan/Stroemberg, 2002, Hellmann/Puri, 2002). Theoretical and empirical studies thus emphasize the advantages of venture capitalists in financing high-tech firms compared to other sources of finance (Admati/Pfleiderer, 1994; Hellmann, 1998; Berger/Udell 1998, Sahlman, 1990).

Although many firms are backed by a sole venture capitalist, a closer look at the working practice of the venture capitalist industry shows striking evidence that investments are often undertaken by more than one venture capitalist. This practice of financing firms by two or more venture capitalists is called syndication and involves a number of different venture capital firms taking an equity stake in the firm. According to Wilson (1968), such a collaboration involves a group of venture capitalists who must make common decisions under uncertainty which result in a payoff that has to be shared jointly among them. In the presence of team-effects and the resulting moral-hazard incentives, the still remaining 
question is, why venture capitalists syndicate private equity, when the practice of syndication may create both, ex-ante and ex-post managerial problems.

This question is addressed empirically in this paper using a hand collected dataset of German IPOs. In more detail, this paper analyzes whether syndicated investments, i.e. firms with multiple venture capitalists differ in their characteristics from firms where only one venture capitalist holds an equity stake. In this vein, the study links venture capital syndication to performance measures like firm growth and stock market performance. The results show that the managerial problems or the costs of syndication are outweighed by the benefits leading to higher growth rates for syndicated firms. Those benefits arise due to a higher amount of equity and the value of information, advice and networking provided by multiple venture capitalists.

Unlike to the US or UK, Germany suffers from having a less developed capital market and a less vibrant venture capital industry. Although being the third-largest economy in the World (behind the US and Japan), Germany is associated with considerably lower growth rates of per capita and of total factor productivity. The US and the UK appear to be better able to cope with such economic problems as the radical and rapid process of structural change from mass production of the industrial sector to the service sector and the increasing importance of the new industries like biotechnology, telecommunication, software, and others (see Audretsch/Thurik, 2001; Rajan/Zingales, 2000). According to Gompers and Lerner (2001), the vibrant venture capital industry is seen as one of the 
cornerstones of America's leadership in the commercialization of technological innovation.

Thus, the lack of a developed venture capital industry to finance young and high-risky firms is one explanation for low growth rates in Germany in the past ten years. The historical advantage of the German bank-based system now turns into a structural and institutional disadvantage. In contrast to banks, equity providers like venture capitalists are more able to overcome the problems of asymmetric information associated with the high risk and thus foster such innovative firms (Hellmann, 1998).

One necessary condition, is a well-functioning and liquid stock market (Black/Gilson, 1998). Active and liquid stock markets make IPOs affordable for companies and attractive for investors. The American experience with the NASDAQ, which provides an equity market for high-tech companies where most of them backed by venture capitalists, is suggestive in this respect.

Although it is proclaimed to be the largest venture capital market in continental Europe (see Bottazi/Da Rin, 2002), there is only scarce empirical evidence about the determinants and the success of venture-backed firms in Germany. The history of the venture capital industry in Germany dates back to the mid-60's of the last century (Becker/Hellmann, 2000) - in contrast to the US, where it dates back to the 40's (Gomper/Lerner, 2001). German venture capitalists also differ from those in the US by their lack of experience (Dittmann et al., 2001, Schefczyk/Gerpott, 2001) and in their organizational form (Becker/Hellmann, 2002; Bascha/Walz, 2001). However, this study is the first one which analyzes the special role of syndication by venture capitalists in Germany. 
The remainder of the paper is as follows. In the next section we summarize the literature on venture capital syndication. The hypotheses on venture-capital syndication are presented in section 3. Section 4 provides the data and how the variables are measured. The descriptive statistics, econometric analysis, and empirical results are discussed in section 5. Section 6 concludes.

\section{Venture Capital Syndication: Risk Sharing and Value Adding}

Although the syndication of private equity by venture capital firms is a widespread phenomenon, it has received disproportionally little attention in the academic literature. Based on this literature, there are mainly two competing views as to why venture capitalists syndicate investments. First, syndication can be viewed as a means of risksharing. Second, venture capitalists may provide important productive resources to firms, capital and information. While the first perspective looks only at the risk-diversification side of the venture capitalist, the second perspective focuses more on the strategic aspects of syndication in providing necessary tangible (equity) and intangible (information) assets.

The risk-sharing hypothesis is mainly put forward by Lerner (1994). The underlying idea is that venture capitalists undertake syndication so as to diversify their portfolio and reduce overall risk. Since firm risk arises from ex ante informational uncertainty regarding investment decisions, syndication of investments by venture capitalists to avoid or share risk is assumed to be highest in early stages of the firms. There is one important 
factor which undermines the risk sharing motive for equity syndication. In contrast to the stock market, the venture capital market is less liquid (Lockett/Wright, 1999). As a result, equity cannot be traded continuously. Therefore, it is important to the venture capitalist to access the diversity of deals at initial investment stages (see Gompers 1995). This risksharing explanation may hold in cases when the lead investor underwrites the whole deal and then subsequently syndicates down the investment to other firms. This, however, may induce adverse effects due to asymmetric information between the lead investor and the uninformed venture capitalists.

Besides the pure risk sharing incentive to syndicate investments, the second perspective looks at the resource side of the firm. From this point of view, syndication is a means of accessing specific resources like capital and advice from multiple firms. First, syndication may lead to a superior selection of investments. Sah and Stiglitz (1986) contrast the decision-making in settings in which projects are undertaken only if one of the parties thinks it worthwhile - hierarchies - and where it is sufficient for both parties to approve the investments - polyarchies. They found it more efficient to undertake those projects that are approved by both parties.

Based on their findings, Lerner (1994) suggests that there may be an advantage to syndication by multiple venture capitalists. He assumes that it might be preferable if the project is evaluated by two separate parties. Two or more independent venture capitalists invest in information gathering, learn from the others' evaluation, and screen the projects more effectively and precisely than one venture capitalist. He confirms his hypotheses of the advantage of syndicated investments with data from the biotechnology sector. 
Recently, Brander et al. (2002) include the framework by Lerner (1994) and enlarge the hypothesis of the selection advantage of multiple venture capitalists by introducing the advantage of value-adding activities by venture capitalists. They base their assumption on the informal literature on the value-adding activities of venture capitalists and on empirical studies showing the advantage of venture capitalists in providing advice and other value-enhancing activities (such as Gompers/Lerner 2001; Gohrman/Sahlman, 1989; Demougin/Fabel, 2004). The results of Brander et al. (2002) clearly show that average returns and growth rates from syndication exceed those from standalone investments.

In the next section we will put forward those two arguments - the risk sharing and the value adding approach - to analyze empirically whether the determinants and effect of venture capital syndication can be explained by either the risk sharing aspect, the value adding argument or both.

\section{Venture Capital Syndication: Determinants and Performance}

We will start this section by arguing whether syndicated investments differ from standalone investments by firm risk and the average amount of equity held by venture capitalists. First, if syndication is undertaken to share risk, we would expect that syndication is more prevalent in high-risky firms. Thus, we formulate the first two hypothesis: 
H1a: The probability of being syndicated increases with firm risk.

H1b: The number of venture capitalists involved in the firm increases with firm risk

A further test of the risk sharing motive for syndication is the amount of equity held by venture capitalists. Although the total amount of equity invested by venture capital firms may be larger compared to standalone investments, the average equity stake should be lower in syndicated investments.

H1c: The average amount of equity held by venture capitalists is lower in syndicated investments

The second argument is based on the value added by venture capitalists. However, information and advice from venture capitalists can only be transformed to firm growth and firm performance if the firm possesses a special kind of receptors. In this vein, Rajan and Zingales (2000) or Fabel (2003) point out that new economy firms differ from others by the modularity of their production function. Especially the complementary within the human capital endowment of the management teams and the complementary between human capital and physical capital are in the focus of researchers (Fabel, 2003; Wasmer/Weil, 2000). Since venture capital firms provide different advice and information, one would expect that the syndication of investment increases with the human capital incorporated by the board of managers and directors. This leads to the following hypothesis:

H2a: Venture capital syndication is positively related to the amount of human capital incorporated by the board of managers and directors. 
Finally, venture capitalists' contribution also depends on new firms' innovation level (Timmons/Bygrave, 1986; Sapienza, 1992). Complementary between the innovation level and the amount of advice and information provided by venture capitalists would lead to the hypothesis:

H2b: Venture capital syndication is positively related to a firm's innovation level.

Next, we will formulate hypotheses about the effect of venture capital syndication for firms. We consider two different measures of firm performance, growth rates and stock market returns.

Since financial resources are one of the most critical obstacles of new firm growth (Berger/Udell, 1998), syndicated investments should have higher growth rates. Also the value adding argument would suggest that firms with multiple venture capitalists should have higher growth rates. Since information and advice are basic resources for firm growth which cannot easily be attracted by the market and thus are private assets for the firm, syndicated investments should be associated with higher growth rates.

H3a: Syndicated investments are associated with higher growth rates than standalone projects.

Finally, we will analyze the effect of venture capital syndication by stock market performance, since the success of the venture capitalists is determined by the market value of the invested equity. If standalone investments are associated with a lower risk, 
receive less information, advice and other supporting value compared to syndicated ventures, the expected returns should also be lower. Thus, syndicated ventures should outperform those firms.

H4a: Syndicated investments outperform standalone investments.

However, if stock markets are efficient, each firm is forced to choose its optimal number of venture capitalists. Thus, the number of venture capitalists or the likelihood of syndication is endogenous and we should not expect that syndicated investments differ from standalone investments in stock market performance. If the syndication of equity is, all else equal, associated with higher stock market returns, this would give an incentive to increase the number of venture capitalists. Thus, we would not expect to find standalone ventures on the stock market. Otherwise, if standalone investments should have higher returns on the stock market, the lead investor has an incentive to cash out the other venture capitalists.

Since we observe that both types - syndicated and standalone investments - are listed on the stock market, the trade-off between the costs and benefits of syndication and standalone investments may lead to the same performance. As an example, the syndication of venture capital is not only associated with a higher risk and thus higher expected returns or a higher value added to the firm, but also with higher ex-ante and expost managerial problems and costs which outweigh the advantage and thus increase with the number of venture capitalists. Such costs may arise by a freeriding behavior as proposed by Holmstrom (1982). Venture capitalists with minor equity stakes have thus a lower incentive to monitor the CEO and to put additional advice. 
On the other side, the double sided moral hazard problem, which is seen to be prevalent in venture capital financed firms (see Schmidt, 2003; Kaplan/Stroemberg, 2002, 2003), may be lower in syndicated investments. The likelihood that the entrepreneur is displaced by venture capitalists is thus higher in standalone investments with lower coordination costs for the lead investor.

The alternative hypothesis is that syndicated investments did not outperform standalone investments:

H4a: Syndicated investments did not differ in their stock market performance from standalone investments.

\section{Data and Measurement}

To conduct this study, we use a hand-collected data set of firms listed on the Neuer Markt in Germany from 1997 until 2002. This market segment for young and highly innovative firms is the German counterpart to the NASDAQ and allows venture capitalists to earn profits by selling their shares. The unique dataset consists of 341 firms listed on the Neuer Markt from 1997 until 2002. From those 341 we dropped all firms located outside Germany, holding companies, banks, firms with a double listing, and non IPO firms. This leads to a set of 285 firms, from which 108 are backed by venture capitalists. Those firms constitute the underlying dataset.

The data are collected by combining individual balance sheet data from IPO prospects with information from the German Patent Office, the Deutsche Boerse AG, Datastream, and OnVista. 
From the IPO prospects we counted the number of venture capitalists who provide equity to the firm (SYNDICATION). The dummy variable STANDALONE is one for venturebacked firms with only one venture capitalist. Furthermore, we include the amount of equity provided by all venture capitalists (VENTURE CAPITAL EQUITY) and the average amount of equity (AVERAGE) hold by venture capitalists.

The first hypothesis states that probability of syndication is positively related to firm risk. Since most firms have no positive revenues in the past - as those in the biotechnology sector - the variance of revenues as a measure of risk is not appropriate since it leads to a selection bias against technology intense and high-risky firms with no revenues. Since we use IPO Data, the variance of the share price in the past as a measure for firm risk is not available. Despite this lack, we use the age (AGE) of a firm before IPO as a measure for firm risk. First, younger firms are associated with a higher degree of asymmetric information for outside financiers. Gathering information is very costly and thus may give an incentive to share those costs and risk with multiple venture capitalists. Second, an overwhelming amount of empirical studies shows that young firms have the highest rates of failure (Caves, 1998; Audretsch, 1995) and thus are associated with a higher firm risk. The age (AGE) of the firm is measured in years since the founding of the company and enters the equation as the natural logarithm. We also include the square term to control for a non-linear effect (AGE-square).

In hypotheses $\mathrm{H} 2 \mathrm{a}$ we assume that the amount of human capital of the members of the board of management and directors positively influences the syndication of a firm. We measure the amount of human capital by the number of academic titles - Doctoral degree 
or Professor - of the members of the management board (TITLE-MANAGEMENT) and the board of directors (TITLE-DIRECTORS).

Beside the human capital the probability of venture capital syndication is assumed to be positively related to the innovation level of a firm. One measure of the innovation level is the amount of money spent on $R \& D$ or the number of employees engaged in $R \& D$ activities. However, firms listed on the Neuer Markt can choose either between USGAAP or IAS as the underlying accounting rule. Both accounting rules differ in the valuation of R\&D spending. Furthermore, firms are also allowed to publish their balancesheet data based on the HGB (Handelsgesetzbuch) for the Pre- and Post IPO year. According to the HGB, it is not allowed to include the value of intangible assets in the balance sheet and they don't have to disclose their spending in R\&D or advertising. To overcome this measurement problem, we include the number of patents owned by the firm (FIRM-PATENTS) until the Pre IPO-year as a measure for the innovation activity level.

Our third hypothesis is that syndicated venture-backed firms differ from standalone venture-backed firms in growth grates. Since some firms, almost especially those in the biotechnology and medicine \& lifestyle sector, show negative earnings or no revenues, we measure growth rates by the number of employees. Thus, the log growth rate (LOGGROWTH) is the difference of the log of the number of employees before IPO and one year after the IPO.

Finally, we take the log of the abnormal rents to measure stock market performance. This variable is created as follows: 
Annual-abnormal-log-rent $=$

$\left\{[\right.$ Inprice(IPO) - lnprice(30.June 02)]-[lnNEMAX(IPO) - $\operatorname{lnNEMAX(30.June02)]~}\} \frac{52}{\text { weeks }}$

Lnprice(IPO) is the natural logarithm of the stock price and lnNEMAX(IPO) is the logarithm of the market index at IPO. Lnprice(30. June. 02) and lnNEMAX(30.June. 02) are the values taken from June, 30, in 2002. Capital increases and dividend payments are considered in the stock prices. The term is divided by the number of weeks from IPO to June, 30, 2002. Multiplying by 52 gives us the annual abnormal rent. The underlying performance measure of abnormal rents measures long time performance from IPO up to the first half of the year 2002. Although no new IPOs are observed in the years 2001 and 2002, we increased the time horizon until June 2002. This six-year time horizon includes both, the dramatically ups - until march 2000 - and downs - from march 2000 until march 2002 - on the stock market.

To control for time effects, we include the IPO Date as a dummy variable for the years 1997-2001. We further include dummy variables for the following industries: Software (SOFTWARE), E-Services (SERVICE), E-Commerce (ECOMMERCE), Computer \& Hardware (COMPUTER), Telecommunication (TELOCOM), Biotechnology (BIOTECH), Medicine \& Life Science (MEDTEC), Media \& Entertainment (MEDIA), and Technology (TECHNOLOGY). Firm size (FIRMSIZE) is measured by the logarithm of the number of employees before IPO. 


\section{Descriptive Statistics and Empirical Results}

\subsection{Descriptive Statistics}

First, we provide the descriptive statistics. Table 1 shows that on average, two venture capitalists are involved in the firm. With standalone investments as the minimum value, the maximum number of venture capitalists involved is 12 . The median firm is eight years old - from foundation until IPO. The number of employees increased drastically after the IPO. The firms also differ in their growth rates and firm patents. While some firms have no registered patent, the maximum number of patents is 52.

Table 2 provides differences between standalone and syndicated investments and reports t-tests of the null hypothesis that the mean of variables for syndicated investments are the same (1) against the (two-sided) alternative hypothesis that they differ (2, 3). About half of the firm is financed by only one venture capitalist at IPO (53 firms) and half are syndicated investments.

On a first view, both standalone and syndicated investments differ significantly in the amount of equity provided to the firm. While standalone projects are financed by less than 20 percent of equity, syndicated investments are on average financed to $25 \%$. Although the means differ between the two groups in the number of employees before and after the IPO, in the age of a firm, and the log growth rates, the differences are not significant on a $10 \%$ level. Interestingly, the number of employees in firms with only one venture capitalist exceeds the mean number of syndicated ventures by about 40 employees. This effect disappears after the IPO. 


\subsection{Determinants of Syndication and the Amount of Venture Capital}

In this section we provide the results from probit and negative binomial estimations (NBE) to analyze the determinants of venture capital syndication (H1a). Then, we take the amount of equity as the endogenous variable to test hypothesis H1b.

In the first model (I), we take the dummy variable SYNDICATION as the endogenous variable. It takes the value one, if more than one venture capitalist holds equity stakes in the firm, and zero, if only one venture capitalist is involved in the firm. The results in table 3 show that none of the explanatory variables significantly explains the syndication of venture capitalists. Also the number of venture capitalists could not be explained significantly by the included variables (model II in table 3). Based on those results, we reject the hypothesis that syndication is more likely in young firms and in firms with intangible assets.

Table 4 predicts that the absolute amount of equity - as measured in percent of total equity - and the average amount of equity differ significantly between standalone and syndicated investments. The equity size held by venture capitalists is larger in syndicated investments. Otherwise, the average size of the equity stake is significantly lower in syndicated investments. The equity stakes held by venture capitalists are significantly positively influenced by firm size. However, firm age as a proxy for firm risk and thus a major explanatory variable for the equity stakes held by venture capitalists, enters the regression insignificantly.

The results also show that equity financing by venture capitalists increased over time. At the beginning of the era of the Neuer Markt, the amount of equity stakes held by venture 
capitalists is significantly lower compared to the following years. The "window of opportunity", as proposed by Ritter (1991) may also hold for venture capital firms. Summing up, the results lead us not to reject hypothesis H1b.

\subsection{Syndication and Performance}

As shown in the previous section, syndicated investments do not differ significantly among firms. This allows us to test directly the hypotheses H3 and H4 by OLS without using instrumental regressions to endogenize the variable SYNDICATION.

First, we test whether syndicated investments show higher growth rates than standalone investments. The results from the OLS regression strongly support this hypothesis. Although, as seen in table 2, the number of employees in standalone investments exceeds those in syndicated investments on average by the number of 40 , the growth rates of syndicated investments after IPO are significantly higher.

Firm size also enters the equation significantly with a negative sign. Although this result contradicts evidence from Gibrat's Law of constant growth rates independently from firm size (Caves, 1998; Sutton, 1997), it is in line with studies based on small and high innovative-firms financed by venture-capitalists (Delmar et al. 2003; Davila et al. 2003). Firms which entered the stock market in the first year in 1997 show significant lower growth rates, compared to those firms which entered in the year 2000.

Finally, we test the two concurrent hypotheses H4a and H4b. The result in table 5 (model II) clearly shows that the dummy variable SYNDICATION is far away from any statistical significant level and leads us to reject hypothesis H4a. Abnormal rents are significantly higher for older firms and for firms which entered the stock market in the 
earliest years. If the squared term of AGE is included - as in the previous regressions - the significant effect of firm age disappears.

The adverse effects of the "New Economy Bubble" is captured and shown by the dummy variables indicating the year of the IPO. Thus, firms which entered the stock market in the earlier years may have a higher "quality" (see also Ritter, 1991; Fama/French, 2002 and Baker/Kennedy, 2003 for such explanations for the NASDAQ).

\subsection{Limitations of the study}

However, data from German firms are hard to collect and are by far not comparable in several aspects with firm data from the US or UK. First, all the data has to be collected "by hand", which restricts the dataset to a smaller number of firms. Second, only the largest firms and firms listed on the stock market have to disclose information. The including of companies that made it to the stock market has the obvious limitation of disregarding what happens to those that are still private. If firms that go public are among the most successful ones, our data set is biased towards those firms. However, the ability to bring companies public is one of the key abilities of venture capitalists, since IPOs are the most lucrative exit from a venture investment (Gompers/Lerner, 1999). If venture capitalists are profit-seekers, we expect them to bring as many of their portfolio companies public as possible, and, if reputation is a crucial asset for their business, we also expect them to select the most promising firms as investees. This, however, should also influence the decision of whether to syndicate an investment or not. Thus, our analysis may overestimate the impact on venture capitalists, a possibility we will return to in the interpretation of the data and results. 
Compared to Lerner (1994) and others, information on the first or lead investor is not available for the researcher. If risk-sharing is more necessary in earlier stages when the venture capital market is less liquid, we would expect less syndicated investments before IPO. Then, our database is biased towards standalone investments and a smaller number of venture capitalists involved. However, syndicated investments are in fact overrepresented in our dataset. Following the annual report of the German Venture Capital Association, e. V. (www.bvk.de), only about 35 to 40 percent of all venture backed firms are syndicated investments. Thus, the listing itself could be interpreted as a determinant of venture capital syndication.

\section{Summary and Conclusion}

The purpose of this study was to analyze empirically whether syndicated investments differ from standalone investments. The results show that both the likelihood of syndication and the number of venture capitalists cannot be explained by firm characteristics like age, size, industry affiliation or the year of the IPO.

However, the study supports the risk-sharing argument, in that the equity shares held by venture capitalists is higher in syndicated investments but also that the average size of equity held by venture capitalists is significantly lower compared to standalone investments.

The study also strongly supports the hypothesis that syndicated ventures show higher growth rates than standalone ventures. This may provide further evidence for the prominent value-adding hypothesis of venture capital syndication. The results also show 
that the resources provided by multiple venture capitalists may lead to higher growth rates by overcoming growth restrictions, but may not necessarily lead to higher returns on the stock market. This result shows that the stock market evaluates the trade-off between the costs and benefits of syndicated firms as the same as for standalone investments.

Thus, from the standpoint of policy makers who are interested in higher growth rates of employees, as it should be the case for Germany, the syndication of equity by venture capitalists should be fostered.

Future research should shed more light on the phenomenon of syndication, both theoretically and empirically. Aspects which are or could not be considered in this study are the double moral hazard effects in syndicated investments, the value added to the firms but also the costs of syndication. 


\section{References}

Admati, Anat R. and Paul Pfleiderer. 1994. Robust Financial Contracting and the Role of Venture Capitalists. Journal of Finance 49: 371-402.

Audretsch, David B. and Roy Thurik .2001. What's New about the New Economy? Sources of Growth in the Managed and Entrepreneurial Economies, Industrial and Corporate Change 10, 267-315.

Baker, George P., and Robert E. Kennedy (2002): Survivorship and the Economic Grim Reaper, Journal of Law, Economics, and Organization (December, forthcoming).

Bascha, Andreas and Uwe Walz (2001): Financing Practices in the German Venture Capital Industry. An Empirical Assessment, working paper, University of Tuebingen.

Becker, Ralf and Thomas Hellmann (2001): The Genesis of Venture Capital - Lessons from the German Experience, working paper Stanford University No. 1705.

Belke, Ansgar; Fehn, Rainer and Neil Foster (2003): Does Venture Capital Spur Emplyoment Growth?, CESifo working paper No. 930, Munich.

Bergemann, Dirk and Uli Hege (1998): Venture Capital Financing, Moral Hazard, and Learning, Journal of Banking and Finance 22, 703-735.

Berger, Allan N. and Greg Udell (1998): The Economics of Small Business Finance: The Role of Private Equity and Dept Markets in the Financial Growth Cycle, Journal of Banking and Finance 22, 613-673.

Black, Bernard and Ronald Gilson (1997): Venture Capital and the Structure of Financial Markets: Banks versus Stock Markets, Journal of Financial Economics 47 (1), 243-277.

Bottazzi, Laura and Marco Da Rin (2002): Venture Capital in Europe and the Financing of Innovative Companies, Economic Policy 17 (1), 229-269.

Brander, James A., Amit, Raphael, and Werner Antweiler (2002): Venture-Capital Syndication: Improved Venture Selection vs. the Value-Added Hypothesis, Journal of Economics and Management Strategy 11 (3), 423-452.

Caves, Richard (1998): Industrial Organization and New Findings on the Turnover and Mobility of Firms, Journal of Economic Literature 36 (4), 1947-1982.

Cumming, Douglas, and Jeffrey G. MacIntosh (2002): A Cross Country Comparison of Full and Partial Venture Capital Exits, Journal of Banking and Finance (forthcoming).

Davila, Antonio; Foster, George, and Mahendra Gupta (2003): Venture capital financing and the growth of startup firms, Journal of Business Venturing 18, 689-708.

Delmar, Frédéric; Davidsson, Per, and William B. Gartners (2003): Arriving at the HighGrowth Firm, Journal of Business Venturing 18 (2), 189-216.

Demougin, Dominique, and Fabel, Oliver (2004): The Division of Ownership in New Ventures, working paper University of Konstanz and HU Berlin. 
Dittmann, Ingolf; Maug, Ernst G. and Johannes Kemper (2001): How Fundamental are Fundamental Values? Valuation Methods and their Impact on the Performance of German Venture Capitalists, working paper, Humbold Unoiversity of Berlin.

Fabel, Oliver (2003):Spin-Offs of Entrepreneurial Firms: An O-Ring approach, Journal if Institutional and Theoretical Economics (forthcoming).

Fama, Eugene and Kenneth R. French (2001): Newly listed firms, fundamentals, survival rates, and returns, Center for Research in Security Prices, Chicago University, working paper no. 530

Gohrman, Michael and William Sahlman (1989): What Do Venture Capitalists Do?, Journal of Business Venturing 4, 231-248.

Gompers, Paul (1995): Optimal Investments, monitoring, and the Staging of Venture capital, Journal of Finance 50 (5), 1461-1489.

Gompers, Paul, and Josh Lerner (2001): The Venture Capital Revolution, Journal of Economic Perspectives 15 (2), 145-168.

Hellmann, Thomas (1998): The Allocation of Control Rights in Venture Capital Contracts, Rand Journal of Economics 29, 57-76.

Hellmann, Thomas and Manju Puri (2000): The Interaction between Product Market and Financing Strategy: The Role of Venture Capital, Review of Financial Studies 13 (4), 959-984.

Hellmann, Thomas and Manju Puri (2002): Venture Capital and the Professionalization of Start-up Firms: Empirical Evidence, Journal of Finance 57 (1), 169-197.

Holmstrom, Bengt (1982): Moral Hazard in Teams, Bell Journal of Economics 10, 74-91.

Kaplan, Steven N. and Per Stroemberg (2004): Characteristics, Contracts, and Actions: Evidence from Venture Capitalist Analysis, Journal of Finance (forthcoming).

Kaplan, Steven N. and Per Stroemberg (2003): Financial Contracting Theory meets the Real World: An Empirical Analysis of Venture Capital Contracts, Review of Economic Studies 70, 281-315.

Lerner, Josh (1995): Venture Capitalists and the Oversight of Private Firms, Journal of Finance 50 (1), 301-318.

Lerner, Joshua (1994): The Syndication of Venture Capital Investments, Financial Management 23 (3), 10-27.

Lockett, Andy and Mike Wright (1999): Venture Capital Syndication, International Journal of Entrepreneurial Finance 1, 303-324.

Rajan, Raghuram and Luigi Zingales (2000): The Governance of the New Enterprise, in: Vives, Xavier (ed.): Corporate Governance, Cambridge University Press.

Ritter, Jay (1991): The Long Run Performance of Initial Public Offerings, Journal of Finance 46, 3-27.

Sah, Raaj. K. and Joseph E. Stiglitz (1986): The Architecture of Economic Systems: Hierarchies and Polyarchies, American Economic Review 76, 716-727. 
Sahlman, William (1990): The Structure and Governance of Venture Capital Organizations, Journal of Financial Economics 27, 473-521.

Sapienza, Harry (1992): When Do Venture Capitals add Value?, Journal of Business Venturing 7, 9-27.

Schefczyk, Michael and Torsten J. Gerpott (2001): Qualifications and Turnover Managers and Venture Capital-Financed Firm Performance. An Empirical Study of German Venture Capital-Investments, Journal of Business Venturing 16 (2), 145-163.

Schmidt, Klaus M. (2003): Convertible Securities and Venture Capital Finance, Journal of Finance 58, 1139-1166

Sutton, John (1997): Gibrat's Legacy, Journal of Economic Literature 35, 40-59.

Timmons, Jeffrey A. and William D. Bygrave (1986): Venture Capital's Role in Financing Innovation for Economic Growth, Journal of Business Venturing 1, 161-176.

Ueda, Masako (2003): Banks versus Venture Capital, Project Evaluation, Screening, and Expropriation, Journal of Finance (forthcoming).

Wilson, Robert (1968), The Theory of Syndicates, Econometrica 36, 119-132. 


\section{Appendix}

\section{Table 1: Descriptive statistics of the data set}

This table provides the descriptive statistics of the included 110 firms before IPO, which are backed by venture capital firms. Syndication refers to those firms which are financed by two or more venture capitalists.

\begin{tabular}{llllll}
\hline Variable & Mean & Stand.Dev. & Median & Min & Max \\
\hline Number of VC & 2.14 & 1.79 & 2 & 1 & 12 \\
Average Share & 22.09 & 18.63 & 18.02 & 0.13 & 76.89 \\
Firm Age & 9.31 & 8.038 & 8 & 0.1 & 35 \\
Employees before IPO & 185.61 & 268.44 & 89 & 2 & 1370 \\
Employees post- IPO & 322.578 & 496.873 & 174 & 10 & 3683 \\
Log growth-rate & 0.588 & 1.534 & 0.498 & -3.236 & 7.518 \\
Firm patents & 3.70 & 10.40 & 0 & 0 & 52 \\
Acad. Titles Board & 0.72 & 0.927 & 0 & 0 & 5 \\
Acad. Titles Directors & 1.65 & 1.221 & 1 & 0 & 5 \\
\hline
\end{tabular}

\section{Table 2: Two-Sample t-tests between Standalone and Syndicated Investments}

This table provides the descriptive statistics of the included 110 firms before IPO. Syndication refers to those firms which are financed by two or more venture capitalists. The underlying null hypothesis of the two-sample t-test is [Mean(Standalone) - Mean(Syndication)]="Difference"=0. H(1): "Difference $<0$; $\mathrm{H}(2)$ : "Difference" $=0$; $\mathrm{H}(3)$ : Difference $>0$; t-values and respective p-values are shown in the table. Degrees of freedom: 108;

\begin{tabular}{lll|ll|llll}
\hline & \multicolumn{2}{c|}{ Mean } & \multicolumn{2}{l}{ Std. Deviation } \\
\hline Variable & Alone & Syndic. & Alone & Syndic. & t-value & H(1) & H(2) & $\mathrm{H}(3)$ \\
\hline Numbers of firms & 53 & 57 & & & & & & \\
Average Share & 18.982 & 24.991 & 20.66 & 16.18 & 1.7045 & 0.045 & 0.091 & 0.954 \\
Firm age & 9.752 & 8.91 & 8.163 & 7.97 & 0.547 & 0.707 & 0.585 & 0.292 \\
Employees before IPO & 208.307 & 164.912 & 302.665 & 233.747 & 0.841 & 0.799 & 0.401 & 0.200 \\
Employees post- IPO & 260.077 & 379.595 & 287.021 & 627.829 & 1.257 & 0.105 & 0.211 & 0.894 \\
Log growth-rate & 0.407 & 0.750 & 1.514 & 1.54 & 1.160 & 0.124 & 0.248 & 0.875 \\
Acad. Titles Board & 0.716 & 0.736 & 0.840 & 1.009 & 0.117 & 0.455 & 0.911 & 0.544 \\
Acad. Titles Directors & 1.622 & 1.678 & 1.004 & 1.415 & 0.237 & 0.406 & 0.813 & 0.593 \\
Firm patents & 2.830 & 4.526 & 8.233 & 12.096 & 0.853 & 0.197 & 0.395 & 0.802 \\
\hline
\end{tabular}




\section{Table 3: Estimation of the likelihood of standalone investments}

This table shows the results of a Probit and Negative Binomial Estimation (NBE). In the first model (I), the dependent variable is a dummy variable which takes the value 1 if the firm is financed by only one venture capitalist and 0 if the firm is financed by two or more venture capitalists. In the second model (II), the number of venture capital firms is taken as the endogenous variable. ***, **, and * denote statistically significant at the 1,5 , and 10 percent levels, respectively. The technology sector and the IPO-Dummy for the year 2000 are taken as the control group. $\mathrm{df}$ is the degree of freedoms.

\begin{tabular}{lll}
\hline & (I) Probit & (II) NBE \\
\hline Variable & Coefficient (z-values) & Coefficient (z-values) \\
Firm patents & $0.0135(0.82)$ & $0.007(0.48)$ \\
Acad. Titles Board & $0.068(0.44)$ & $0.052(0.32)$ \\
Acad. Titles Directors & $0.060(0.49)$ & $0.053(0.41)$ \\
LNSIZE & $0.146(1.13)$ & $0.074(0.56)$ \\
LNAge & $0.095(0.78)$ & $0.057(0.44)$ \\
LNAge2 & $-0.039(0.71)$ & $-0.017(0.30)$ \\
IPO 97 & $0.298(0.38)$ & $0.363(0.40)$ \\
IPO 98 & $-0.240(0.42)$ & $-0.103(0.16)$ \\
IPO99 & $-0.054(0.18)$ & $-0.028(0.09)$ \\
Software & $0.206(0.42)$ & $0.189(0.35)$ \\
Service & $-0.305(0.75)$ & $-0.237(0.50)$ \\
E-Commerce & $1.696(2.21) * *$ & $0.865(1.49)$ \\
Computer \& Hardware & $-0.808(1.34)$ & $-0.795(0.97)$ \\
Telecommunication & $0.058(0.11)$ & $0.113(0.20)$ \\
Biotechnology & $0.705(0.94)$ & $0.326(0.48)$ \\
Medicine \& Life Science & $0.612(1.00)$ & $-0.494(0.63)$ \\
Media \& Entertainment & $0.759(1.43)$ & $0.491(0.95)$ \\
Constant & $-0.826(1.29)$ & $-1.242(1.77)^{*}$ \\
\hline LL & -65.323 & -88.944 \\
\hline Pseudo R-squared & 0.110 & 0.043 \\
LR Chisquare (df) & $16.26(16)$ & $7.67(17)$ \\
N & 106 & 108 \\
\hline
\end{tabular}




\section{Table 4: Estimation of the equity held by venture capitalists}

The dependent variable is the amount of equity held by venture capitalists before IPO and the average amount of equity held by a venture capitalist. The data are not censored on the left (zero) and right (100) side. $* * *, * *$, and $*$ denote statistically significant at the 1,5 , and 10 percent levels, respectively. All regressions are run using the White-heteroskedasticity consistent estimator. The technology sector and the IPO-Dummy for the year 2000 are taken as the control group.

\begin{tabular}{lll}
\hline & Total Equity & Average Equity \\
\hline Variable & Coefficient (t-values) & Coefficient (t-values) \\
\hline Syndication & $7.049(2.13)^{* *}$ & $-8.177(2.94)^{* * *}$ \\
Firm patents & $0.114(0.67)$ & $0.063(0.36)$ \\
Acad. Titles Board & $0.384(0.19)$ & $1.302(0.87)$ \\
Acad. Titles Directors & $2.197(1.43)$ & $0.986(0.81)$ \\
LNSIZE & $4.462(2.96)^{* * *}$ & $3.441(2.54)^{* *}$ \\
LNAge & $-1.328(0.78)$ & $-0.225(0.18)$ \\
LNAge2 & $-0.760(0.96)$ & $-0.863(1.35)$ \\
IPO97 & $-16.667(3.07)^{* * *}$ & $-8.739(1.69)^{*}$ \\
IPO 98 & $2.640(0.35)$ & $2.323(0.32)$ \\
IPO99 & $3.947(0.94)$ & $3.168(0.87)$ \\
Software & $2.467(0.65)$ & $2.682(0.91)$ \\
Service & $4.894(1.07)$ & $5.959(1.52)$ \\
E-Commerce & $13.746(1.99)^{*}$ & $8.482(2.06)^{* *}$ \\
Computer \& Hardware & $13.691(1.74)^{*}$ & $14.369(1.78)^{*}$ \\
Telecommunication & $9.636(1.24)$ & $8.909(1.28)$ \\
Biotechnology & $10.346(1.21)$ & $2.641(0.50)$ \\
Medicine \& Life Science & $7.878(1.33)$ & $8.763(1.68)^{*}$ \\
Media \& Entertainment & $12.619(1.73)^{*}$ & $10.826(2.27)^{* *}$ \\
Constant & $-8.494(1.19)$ & $-3.260(0.54)$ \\
\hline Adj. R-squared & 0.264 & 0.295 \\
N & 108 & 108 \\
\hline
\end{tabular}




\section{Table 5: OLS Estimation of growth rates and abnormal returns}

The dependent variable is the growth rate of firms and is measured by the difference of the log(employees) before and after IPO. ***,**, and * denote statistically significant at the 1,5 , and 10 percent levels, respectively. All regressions are run using the White-heteroskedasticity consistent estimator. The technology sector and the IPO-Dummy for the year 2000 are taken as the control group.

\begin{tabular}{lll}
\hline & (I) Growthrate & (II) Abnormal Rent \\
\hline Variable & Coefficient (t-values) & Coefficient (t-values) \\
\hline Syndication & $0.5223(2.26)^{* *}$ & $-0.174(0.98)$ \\
Firm patents & $0.0118(0.75)$ & $-0.0006(0.12)$ \\
Acad. Titles Board & $0.088(0.74)$ & $-0.067(0.88)$ \\
Acad. Titles Directors & $0.102(0.96)$ & $0.039(0.66)$ \\
LNSIZE & $-0.874(7.13)^{* * *}$ & $0.1068(1.48)$ \\
LNAge & $0.075(0.65)$ & $0.1068(2.17)^{* *}$ \\
LNAge2 & $-0.064(1.26)$ & - \\
IPO 97 & $-1.258(2.29)^{* *}$ & $1.795(4.12)^{* * *}$ \\
IPO 98 & $-0.034(0.09)$ & $1.369(8.84)^{* * *}$ \\
IPO 99 & $-0.177(0.68)$ & $0.750(3.86)^{* * *}$ \\
Software & $-0.124(0.31)$ & $-0.343(1.40)$ \\
Service & $0.679(2.37)^{* *}$ & $-0.523(1.63)$ \\
E-Commerce & $-0.611(1.27)$ & $-0.150(0.44)$ \\
Computer \& Hardware & $-0.611(1.27)$ & $0.0299(0.12)$ \\
Telecommunication & $0.321(0.63)$ & $-0.072(0.37)$ \\
Biotechnology & $0.428(0.53)$ & $0.392(2.10)^{* *}$ \\
Medicine \& Life Science & $0.486(1.08)$ & $-0.1420(0.35)$ \\
Media \& Entertainment & $0.032(0.07)$ & $-0.302(1.48)$ \\
Constant & $4.002(6.13)^{* * *}$ & $-0.2763(5.49)^{* * *}$ \\
\hline Adj. R-squared & 0.561 & 0.399 \\
N & 107 & 107 \\
\hline
\end{tabular}

